Cudowska-Sojko A., BIZ jako forma ekspansji KTN we wspótczesnej gospodarce „Ekonomia i Prawo", Polszakiewicz B., Boehlke J. (red.), Tom XII, nr 3/2013, ss. 371-383. DOI: http:// dx.doi.org/10.12775/EiP.2013.028

ANNA CUDOWSKA-SOJKO*

\title{
BIZ JAKO FORMA EKSPANSJI KTN WE WSPÓŁCZESNEJ GOSPODARCE
}

\section{STRESZCZENIE}

Artykuł dotyczy wpływu korporacji transnarodowych na oblicze współczesnej gospodarki. Korporacje transnarodowe są obecnie najpotężniejszymi organizacjami gospodarczymi świata, mającymi wpływ na wiele podmiotów i procesów we współczesnej gospodarce globalnej. Dokonuje się to głównie przez Bezpośrednie Inwestycje Zagraniczne.

Słowa kluczowe: BIZ, KTN

Klasyfikacja JEL: F15, F23

\section{DFI AS A FORM OF EXPANSION TRANSNATIONAL CORPORATIONS IN CONTEMPORARY ECONOMY}

\section{SUMMARY}

The article concerns analyses the influence of transnational corporations in world modern economy. Transnational corporations are now the most powerful economic organizations of the world, affecting the many of entities and processes in the modern global economy. This is done mainly through FDI.

Keywords: FDI, transnational corporations, modern economy

JEL Classification: F15, F23

* Anna Cudowska-Sojko, Uniwersytet w Białymstoku, Wydział: Ekonomii i Zarządzania, Katedra Ekonomii Politycznej, tel.: +48 509611 778, e-mail: a.cudowskasojko@uwb.edu.pl. 


\section{WSTĘP}

Korporacje są podmiotami determinującymi rozwój gospodarczy gospodarek narodowych i ugrupowań regionalnych we współczesnym świecie, głównie przez międzynarodowe przepływy kapitałowe w formie Bezpośrednich Inwestycji Zagranicznych. Napływ BIZ jest głównym przedmiotem zainteresowania gospodarek narodowych i organizacji gospodarczych, ze względu na znaczący wpływ na stan gospodarki, jak również ich wielkość traktuje się jako miernik pozycji konkurencyjnej państwa przyjmującego. Celem artykułu jest przybliżenie zagadnienia roli KTN i ich możliwości oddziaływania poprzez BIZ na współczesną gospodarkę.

\section{ISTOTA KORPORACJI TRANSNARODOWYCH}

Korporacje transnarodowe KTN są obok państw narodowych głównym podmiotem rynku globalnego i największym beneficjentem procesu globalizacji ${ }^{1}$. KTN wpływają na przemiany w gospodarce światowej. Określenie istoty KTN nie jest łatwym zadaniem ze względu na ich zróżnicowanie, a także złożoność. Nie istnieje również jedna obowiązująca definicja ${ }^{2}$. W literaturze ekonomicznej dość szeroko omówiono już podmioty gospodarcze, które prowadzą działalność w różnych krajach i dokonują w nich inwestycji bezpośrednich. Związana $\mathrm{z}$ nimi terminologia jest jednak bardzo zróżnicowana. Nazywane są korporacjami międzynarodowymi (lub przedsiębiorstwami), wielonarodowymi, ponadnarodowymi lub transnarodowymi ${ }^{3}$. Najbardziej znaną definicją, którą ekonomiści posługują się dość powszechnie, jest definicja sformułowana przez UNCTAD. W tym ujęciu KTN są to przedsiębiorstwa będące spółką kapitałową, które składają się z przedsiębiorstw macierzystych i ich filii zagra-

${ }^{1}$ M. Ciecierski, Wywiad Biznesowy w korporacjach transnarodowych, Wydawnictwo Adam Marszałek, Toruń 2009, s.133; K. Kuciński, Glokalizacja, Difin, Warszawa 2011, s. 32.

2 A. Zaorska, Korporacje transnarodowe, przemiany, oddziatywania, wyzwania, PWE, Warszawa 2007, s. 121; J. Urbanek, Ewolucja modeli organizacyjnych w korporacjach transnarodowych, a korporacje transnarodowe przysztości, [w:] red. J. Rymarczyk, Rozwój regionalny i globalny we wspótczesnej gospodarce światowej, WAE, Wrocław 2005, s. 385; B. Stępien, Przedsiębiorstwo międzynarodowe - trudności analityczne, [w:] red. J. Schroeder, Perspektywy i kierunki rozwoju przedsiębiorstw międzynarodowych, Poznań 2006, s. 61-65.

${ }^{3}$ E. Fojutowski, Strategie przedsiębiorstw krajowych wobec ekspansji korporacji transnarodowych. Uwarunkowania regionalne, WSNHiD, Poznań 2011, s. 17-18; K. Marzęda, Proces globalizacji korporacyjnej, Branta, Bydgoszcz - Warszawa - Lublin 2007, s. 40-43; K. Sowa, Strategie konkurencji korporacji ponadnarodowych, Difin, Warszawa 2006, s. 32-33. 
nicznych. Przedsiębiorstwem macierzystym jest przedsiębiorstwo, które kontroluje aktywa innych podmiotów w krajach poza krajem macierzystym, będąc zwykle w posiadaniu pewnego udziału w kapitale własnym tych podmiotów. Udział w kapitale własnym, wynoszący co najmniej 10\% zwykłych akcji, lub prawo głosu na walnym zebraniu akcjonariuszy uważa się zazwyczaj jako granicę kontroli aktywów. Zagraniczna filia jest spółką kapitałową, w której inwestor będący rezydentem innego kraju ma udział kapitałowy (co najmniej 10\%), umożliwiający trwały wpływ na zarządzanie tym przedsiębiorstwem. W publikacjach UNCTAD wyróżnia się trzy formy bezpośredniej obecności firmyinwestora za granicą. Zasadniczą formą są filie z pełnym lub większościowym udziałem kapitałowym - powyżej 50\% i prawem inwestora do decydującego głosu oraz wpływu na jej organy, administracyjne i zarządzanie. Filie mogą też być spółką stowarzyszoną lub mieszaną, albo być wspólnym przedsięwzięciem z udziałem 10-50\% kapitału własnego z odpowiednim prawem głosu. Trzecią formą jest oddział tylko reprezentujący inwestora lub będący wspólnym przedsięwzięciem o niewielkim zaangażowaniu kapitałowym (poniżej 10\%) czy też posiadającym co najmniej przez rok majątek nieruchomy lub ruchomy ${ }^{4}$.

Schemat 1. Struktura KTN w ujęciu UNCTAD

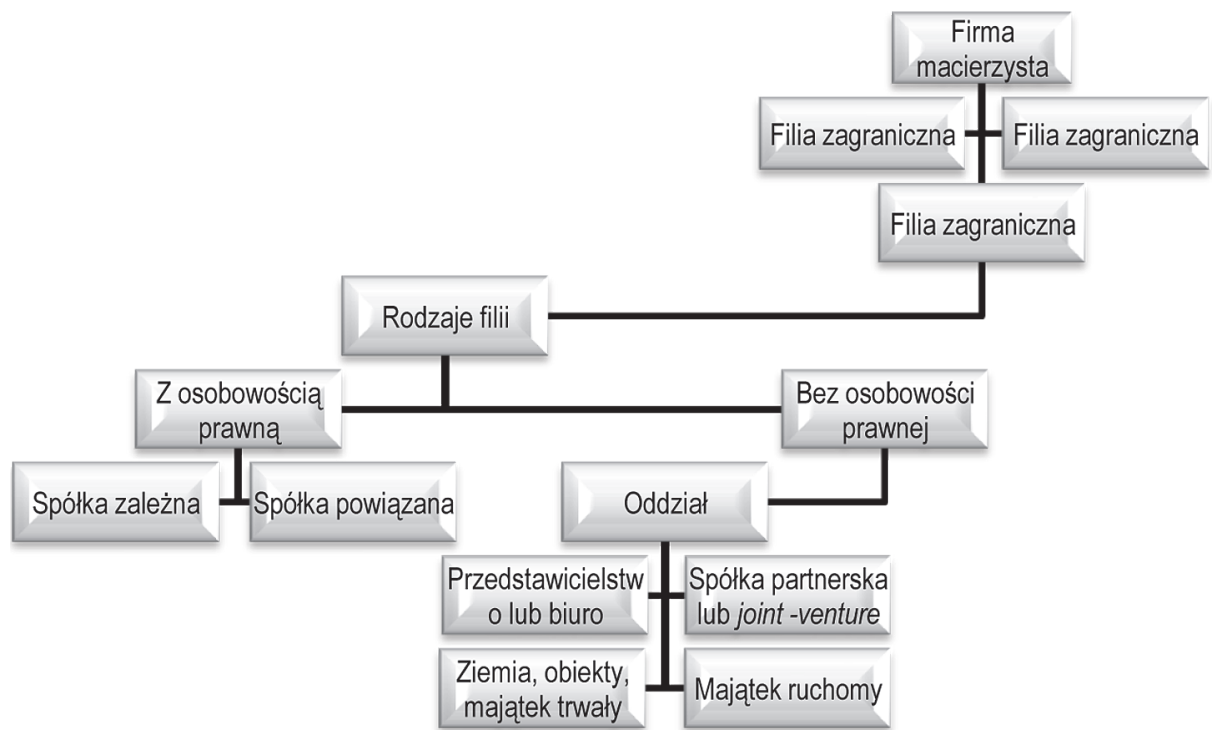

Źródło: M. Ciecierski, Wywiad Biznesowy w korporacjach transnarodowych, Wydawnictwo Adam Marszałek, Toruń 2009, s. 139.

${ }^{4}$ A. Zaorska, Korporacje transnarodowe, przemiany, oddziatywania, wyzwania, PWE, Warszawa 2007, s. 122. 
Wśród cech charakterystycznych, jakie określają działania korporacji transnarodowych we współczesnej gospodarce należy wyróżnić:

- suwerenność - dotyczy podejmowania strategicznych decyzji, działań;

- złożoność - obejmuje problematykę własnościową, organizacyjną, kontrolną, przestrzenną;

- rozproszenie - dotyczy rozproszenia geograficznego, problematyki innowacyjnej oraz produkcyjno-handlowej;

- specjalizację - wybranie segmentu produktu oferowanego następnie na rynku globalnym;

- zdolność arbitrażowania - podejmowanie i prowadzenie działalności gospodarczej na różnych rynkach;

- zdolność integrowania - tworzenie powiązań kooperacyjnych;

- elastyczność organizowania - koordynacja działań na różnych rynkach, krajach;

- globalną efektywność - wyraża się między innymi przez podejmowanie badań w różnych częściach świata czy realizowanie rozmaitych przedsięwzięć dotyczących produkcji lub sprzedaży produktów ${ }^{5}$.

Schemat 2. Cechy korporacji transnarodowych
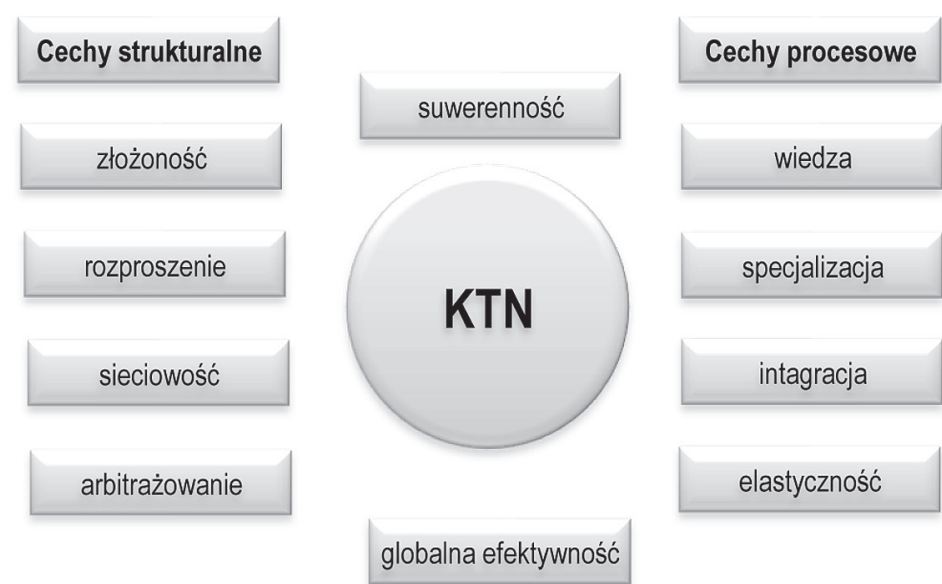

Źródło: A. Zaorska, Korporacje transnarodowe. Przemiany, oddziaływania, wyzwania, PWE, Warszawa 2007, s. 127.

5 A. Zaorska, Korporacje transnarodowe, przemiany, oddziatywania, wyzwania, PWE, Warszawa 2007, s. 126-132; P. Marzec, Korporacje transnarodowe w procesie globalizacji gospodarki swiatowej, [w:] T. Guz, K. A. Kłosiński, P. Marzec (red.), Polska, Europa, Świat. Korporacje transnarodowe, Polihymnia, Lublin-Tomaszów Lubelski 2007 s. 36. 
Przedsiębiorstwa Transnarodowe poprzez swoją aktywność oddziaływają na wiele elementów światowego systemu społeczno-gospodarczego. Szczególnie dostrzega się ich istotny wpływ w następujących obszarach ${ }^{6}$ :

- rozmiarze, strukturze i kierunkach przepływu kapitału;

- rozprzestrzenianiu się osiągnięć technologicznych w skali międzynarodowej;

- strukturalnych i geograficznych zmianach w produkcji, konsumpcji, światowym handlu;

- konkurencyjności;

- globalnej dystrybucji i redystrybucji dochodów;

- kierunkach wykorzystania potencjału ludzkiego;

— organizacji i strukturze współpracy międzynarodowej.

\section{KTN W GOSPODARCE GLOBALNEJ}

Globalizacja jest zjawiskiem wszechobecnym i wszyscy są zgodni co do tego, że przejawia się ona poprzez procesy zachodzące we wszystkich obszarach funkcjonowania współczesnej gospodarki ${ }^{7}$. Korporacje transnarodowe stały się ważnym elementem krajobrazu gospodarczego dzisiejszych czasów i to zarówno z punktu widzenia gospodarki światowej, jak i krajów goszczących ich zagraniczne filie ${ }^{8}$. O znaczącym wpływie KTN na proces globalizacji decyduje ich duży potencjał i ekspansja w gospodarce światowej, często wyrazem jest ich wiodąca rola w bezpośrednich inwestycjach zagranicznych ${ }^{9}$. Przepływy pieniężne największych korporacji świata są dzisiaj porównywalne pod względem wartości z gospodarką fiskalną małych, a nawet średnich państw. Dla przykładu, łączne średnioroczne nakłady największych firm motoryzacyjnych świata na badania i rozwój wystarczyłyby na pokrycie obecnego deficytu budżetowego Polski ${ }^{10}$.

${ }^{6}$ M. E. Sokołowicz, Region w gospodarce globalnej - bezpośrednie inwestycje zagraniczne a rozwój regionu, [w:] A. Nowakowska, Z. Przygodzki, M.E. Sokołowicz (red.), Region w gospodarce opartej na wiedzy, Difin, Warszawa 2011, s. 135.

7 B. Drelich-Skulska, P. Skulski, Specyfika biznesu międzynarodowego w Azji Wschodniej na tle procesów globalizacji, [w:] E. Najlepszy, M. Bartosik-Purgat (red.), Determinanty i wyzwania gospodarki światowej, UE, Poznań 2009, s. 132.

${ }^{8}$ M. Kuzel, Rola Bezpośrednich Inwestycji Zagranicznych w dyfuzji wiedzy i umiejętności, Dom Organizatora, Torun 2007, s. 126.

${ }^{9}$ T. Pakulska, M. Poniatowska-Jaksch, Korporacje transnarodowe a globalne pozyskiwanie zasobów, SGH, Warszawa 2009, s. 35; M. Dzikowska, Wptyw kryzysu finansowego i ekonomicznego na dziatalnośc korporacji transnarodowych w latach 2008-2010, [w:] J. Schroeder (red.), Przedsiębiorstwo na rynku międzynarodowym, WUE, Poznań 2011, s. 32.

${ }^{10} \mathrm{~K}$. Waśniewski, Decyzje inwestycyjne wspótczesnej korporacji - dylematy racjonalności, KTE, Kraków 2011, s. 7. 
Tabela 1. Międzynarodowa statystyka dotycząca KTN (w mld USD)

\begin{tabular}{|c|r|r|r|r|r|r|r|r|}
\hline LATA & 2004 & 2005 & 2006 & 2007 & 2008 & 2009 & 2010 & 2011 \\
\hline Napływ BIZ & 648 & 946 & 1306 & 1979 & 1697 & 1198 & 1309 & 1524 \\
\hline Zasoby BIZ & 8902 & 10048 & 11999 & 15660 & 14909 & 18041 & 19907 & 20438 \\
\hline Międzynarodowe fuzje i przejęcia & 381 & 716 & 880 & 1031 & 673 & 250 & 344 & 526 \\
\hline Sprzedaż zagranicznych filii KTN & 18677 & 21394 & 25177 & 31764 & 30311 & 23866 & 25622 & 27877 \\
\hline Wartość dodana KTN & 3911 & 4184 & 4862 & 6295 & 6020 & 6392 & 6560 & 7183 \\
\hline Aktywa zagraniczne filii KTN & 36008 & 42637 & 51187 & 73457 & 69771 & 74910 & 75609 & 82131 \\
\hline Eksport zagranicznych filii KTN & 3690 & 4197 & 4707 & 5775 & 6664 & 5060 & 6267 & 7358 \\
\hline $\begin{array}{c}\text { Zatrudnienie w zagranicznych fi- } \\
\text { liach (w tys.) }\end{array}$ & 57394 & 63770 & 72627 & 80396 & 77386 & 59877 & 63903 & 69065 \\
\hline \multicolumn{7}{|c|}{ Świat: } \\
\hline PKB ceny bieżące & 40671 & 44486 & 48293 & 55114 & 60780 & 57920 & 63075 & 69660 \\
\hline Inwestycje w kapitał trwały & 8869 & 9115 & 10307 & 12399 & 13824 & 12735 & 13940 & 15770 \\
\hline Tantiemy i opłaty licencyjne & 98 & 123 & 132 & 163 & 177 & 200 & 218 & 242 \\
\hline Eksport towarów i usług & 11069 & 12588 & 14120 & 17321 & 19990 & 15196 & 18821 & 22095 \\
\hline
\end{tabular}

Źródło: World Investment Report 2012, UNCTAD, s. 24; World Investment Report 2009, UNCTAD, s. 18, World Investment Report 2007, UNCTAD, s. 9, World Investment Report 2005, UNCTAD, s. 14.

Tabela 2. Ranking największych niefinansowych transnarodowych korporacji w 2011 roku (w mld USD)

\begin{tabular}{|c|c|c|c|c|c|c|r|}
\hline \multirow{2}{*}{ LP. } & \multirow{2}{*}{ FIRMA } & \multicolumn{2}{|c|}{ AKTYWA } & \multicolumn{2}{c|}{ SPRZEDȦ } & \multicolumn{2}{c|}{ ZATRUDNIENIE } \\
\cline { 3 - 8 } & & ZAGRANICA & OGÓtEM & ZAGRANICA & OGótem & ZAGRANICA & OGótem \\
\hline 1 & General Electric Co & 502612 & 717242 & 77480 & 147300 & 170000 & 301000 \\
\hline 2 & Royal Dutch Shell & 296449 & 345257 & 282673 & 470171 & 75000 & 90000 \\
\hline 3 & BP & 263577 & 293068 & 308437 & 386463 & 68005 & 83433 \\
\hline 4 & Exxon Mibil Co & 214231 & 331052 & 316686 & 433526 & 49496 & 82100 \\
\hline 5 & Toyota Motor Co & 214117 & 372566 & 142888 & 235200 & 123655 & 325905 \\
\hline 6 & Total SA & 211314 & 228036 & 197480 & 256732 & 61067 & 96104 \\
\hline 7 & GDF Suez & 194422 & 296650 & 82731 & 126040 & 110554 & 218873 \\
\hline 8 & Vodafone Group & 171941 & 186176 & 65448 & 74089 & 75476 & 83862 \\
\hline 9 & Enel & 153665 & 236037 & 66817 & 110528 & 36656 & 75360 \\
\hline 10 & Telefonica SA & 147903 & 180186 & 63014 & 87346 & 231066 & 286145 \\
\hline
\end{tabular}

Źródło: World Investment Report 2012, UNCTAD.

Rola KTN w gospodarce światowej systematycznie wzrasta. Analiza zamieszczonych powyżej danych umożliwia dokonanie kilku uwag odnośnie do roli korporacji w gospodarce światowej. Przedsiębiorstwa filialne KTN wytwarzają około $10 \%$ światowego $\mathrm{PKB}$, a ich udział w światowym eksporcie wynosi około $30 \% \mathrm{w}$ ostatnich latach. Jeszcze wyraźniej to widać na podstawie danych z tabeli 2., odnoszącej się do aktywów, sprzedaży i zatrudnienia w nie- 
finansowych KTN z samego szczytu listy. Te firmy od lat są w czołówce, jedynie na „chwilę” zmieniając pozycję o kilka punktów.

Ważną cechą korporacji transnarodowych z punktu widzenia ich wpływu na gospodarkę jest nie tylko ich wielkość (wysoka wartość aktywów, zatrudnienia), ale także oddziaływanie na wzrost gospodarczy poprzez bezpośrednie inwestycje, których są ważnym źródłem, oraz poprzez eksport ${ }^{11}$.

\section{BIZ W PROCESIE GLOBALIZACJI}

Brak wewnętrznej akumulacji kapitału w wielu rozwijających się krajach prowadzą do poszukiwania różnych źródeł finansowania gospodarki, wśród których istotną rolę odgrywają bezpośrednie inwestycje zagraniczne ${ }^{12}$. W dobie globalizacji gospodarki światowej i nasilającej się konkurencji na rynkach międzynarodowych wiele krajów zabiega o przyciągnięcie z zagranicy jak najwięcej kapitału ${ }^{13}$. Pojęcie korporacji transnarodowych jest ściśle związane z pojęciem bezpośrednich inwestycji zagranicznych (BIZ), ponieważ to właśnie za pośrednictwem korporacji transnarodowych dokonywane są bezpośrednie inwestycje zagraniczne ${ }^{14}$. Należy jednak dodać, że korporacja transnarodowa jest pojęciem szerszym od bezpośrednich inwestycji zagranicznych, ponieważ jest ona instytucjonalnym wyrazem lokaty kapitału, a jednocześnie do jej istoty należy produkcja, dystrybucja i inne kwestie związane $z$ bezpośrednią działalnością na obcych rynkach ${ }^{15}$. BIZ stanowią szczególną formę zaangażowania kapitałowego podejmowanego poza granicami kraju macierzystego. Są one lokatami kapitału, których istotę stanowi przenoszenie całości lub części czynników wytwórczych poza granice kraju macierzystego w celu czerpania dłu-

${ }^{11}$ K. Piech, Integracja rynków finansowych w Unii Europejskiej, NBP, Warszawa 2007, s. 11; S.M. Lundan, An institutional perspective on the social responsibility of TNCs, "Transnational Corporation," 2011, vol. 3, s. 70.

12 E. Frejtag-Mika, Architektura finansowa globalnej wspótpracy na rzecz rozwoju - wyzwania milenijne, [w:] J. L. Bednarczyk, S. I. Buowski, J. Misala (red.), Globalne rynki finansowe w dobie kryzysu, CeDeWu, Warszawa 2009, s. 126; A. Szelągowska, Inwestycje międzynarodowe przedsiębiorstw, [w:] A. Kosztowniak, P. Misztal, I. Pszczółka, A. Szelągowska (red.), Finanse i rozliczenia międzynarodowe, C.H. Beck, Warszawa 2009, s. 403.

13 J. Bednarz, E. Gostomski, Pozyskiwanie kapitatu na dziatalnośc gospodarczq na rynkach zagranicznych, WUG, Gdańsk 2008, s. 131.

${ }_{14}$ M. Lech, Zdolność oddziatywania korporacji transnarodowych na wspótczesne stosunki międzynarodowe w dobie procesu globalizacji, [w:] J. Menkes, T. Gardocka (red.), Korporacje transnarodowe, Academika, Warszawa 2010, s. 216.

${ }_{15}$ T. Sporek, Wptyw kryzysu finansowego na globalizacje gospodarki swiatowej. Diagnoza i konsekwencje dla Polski, WAE, Katowice 2010, s. 278. 
gofalowych korzyści z tytułu zaangażowania zagranicznego ${ }^{16}$. Przedmiotem zainteresowania inwestora jest sama działalność i wyniki przedsiębiorstwa oraz jego perspektywy rozwojowe. Inwestycje bezpośrednie to nie tylko przepływ środków finansowych, ale także całego pakietu zasobów niematerialnych, które są transferowane do zagranicznych filii lub oddziałów, stwarzając im podstawy do skutecznego konkurowania $\mathrm{z}$ podmiotami lokalnymi ${ }^{17}$. Jednakże w większości opracowań bazuje się na definicjach MFW i OECD. Chodzi tu przede wszystkim o możliwość porównywania danych $\mathrm{z}$ wielu krajów, zbieranych $\mathrm{w}$ oparciu o ten sam system gromadzenia i interpretacji danych. Według definicji wzorcowej, opracowanej przez OECD, inwestycją zagraniczną jest przedsiębiorstwo, w którym jeden inwestor zagraniczny uzyskuje lub ma „trwały wpływ”, wyrażony posiadaniem minimum $10 \%$ głosów na walnym zgromadzeniu akcjonariuszy ${ }^{18}$.

Zgodnie z metodologią OECD zagraniczne inwestycje bezpośrednie podzielić można na:

- przedsiębiorstwa zależne, nad którymi inwestor zagraniczny sprawuje pełna kontrolę, dzięki posiadaniu więcej niż połowy udziałów lub praw do powoływania i odwoływania większości członków zarządów lub organu nadzorującego działalność przedsiębiorstwa;

- przedsiębiorstwa stowarzyszone, posiadające odrębną osobowość prawną, w których inwestor zagraniczny kontroluje od 10\% do 50\% akcji zwykłych bądź udziałów;

- oddziały niebędące samodzielnymi jednostkami gospodarczymi i nie posiadające osobowości prawnej, mogące występować w formie oddziału założonego na pewien okres w celu prowadzenia działalności gospodarczej za granicą bądź biura lub spółki typu joint venture.

Takie ujęcie istoty BIZ oznacza, że polegają one nie tylko na tworzeniu nowych (greenfield) lub przejmowaniu przedsiębiorstw już istniejących (brownfield) poza granicami kraju osiedlenia inwestora. Obejmują bowiem również przekazywanie licencji, patentów, know-how, praw autorskich w zamian za

16 J. Macias, Nowa strategia transnarodowa korporacji międzynarodowych - globalna standaryzacja i lokalna wrażliwość, „Przegląd Organizacji”, nr. 9/2010, s. 8.

${ }_{17}$ M. Kola-Bezka, M. Kuzel, I. Sobczak, BIZ w województwie kujawsko-pomorskim, WSG, Bydgoszcz 2009, s. 13-14.

${ }_{18}$ G. Garniewicz, P. Siemiątkowski, Wprowadzenie do międzynarodowych przeptywów kapitatu, Wydawnictwo „Dom Organizatora”, Toruń 2006, s. 87; M. Kolarz, Wptyw zagranicznych inwestycji bezpośrednich na innowacyjnośc przedsiębiorstw w Polsce, WUS, Katowice 2006, s. 10-11; Benchmark Definition of Foreign Direct Investment, OECD, Paris 1996, s. 8. 
udziały własnościowe. Do BIZ można zaliczyć również przepływy kapitałowe w formie pożyczek, kredytów, darowizn oraz reinwestowane zyski ${ }^{19}$.

Tabela 3. Tempo wzrostu PKB, handlu, zatrudnienia i BIZ na świecie w latach 2008-2012 (w \%)

\begin{tabular}{|c|r|r|r|r|r|}
\hline LATA & 2008 & 2009 & 2010 & 2011 & $2012^{*}$ \\
\hline PKB & 1,4 & $-2,1$ & 4,0 & 2,7 & 2,3 \\
\hline Handel & 3,0 & $-10,4$ & 12,6 & 5,8 & 3,2 \\
\hline Zatrudnienie & 1,1 & 0,4 & 1,4 & 1,5 & 1,3 \\
\hline BIZ & $-9,5$ & $-33,0$ & 14,1 & 16,2 & $-18,3$ \\
\hline
\end{tabular}

* szacunek

Źródło: Global FDI recovery derails, "Global Investment Trends Monitor" 2013, nr 11, s. 2.

Niestety, echo kryzysu lat 2008-2009 jest przewidywane w spadku tempa BIZ na świecie na najbliższe lata. Ta sytuacja ma się poprawić w najbliższych dwóch latach.

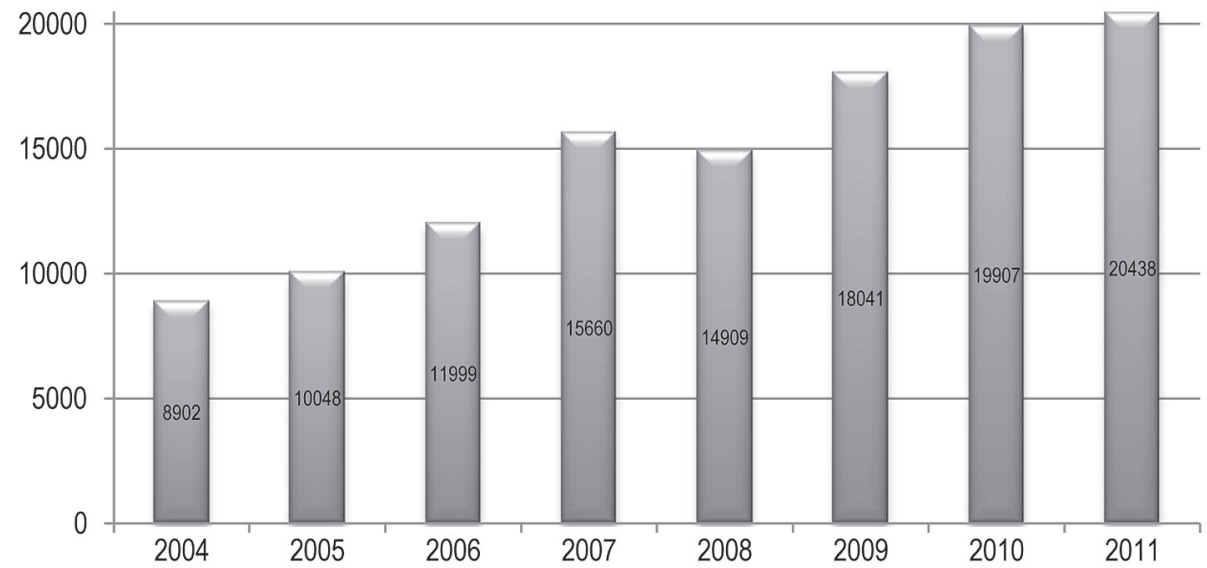

Wykres 1. Światowe zasoby BIZ w latach 2004-2011 (w mld USD)

Źródło: World Investment Report 2012, UNCTAD, s. 24, World Investment Report 2009, UNCTAD, s. 18, World Investment Report 2007, UNCTAD, s. 9, World Investment Report 2005, UNCTAD, s. 14.

Podstawą ekspansji KTN są bezpośrednie inwestycje zagraniczne których zasoby wzrastały w latach 2004-2007 i w latach 2009-2011, spadek tej wielkości w 2008 roku był związany z światowym kryzysem.

19 M. Kolarz, Wptyw zagranicznych inwestycji... op. cit., s. 12, por. J. Franc-Dąbrowska, M. Porada-Rochoń, Bezpośrednie inwestycje zagraniczne - perspektywa międzynarodowa, „Przegląd Organizacji”, nr 4/2010, s. 28. 


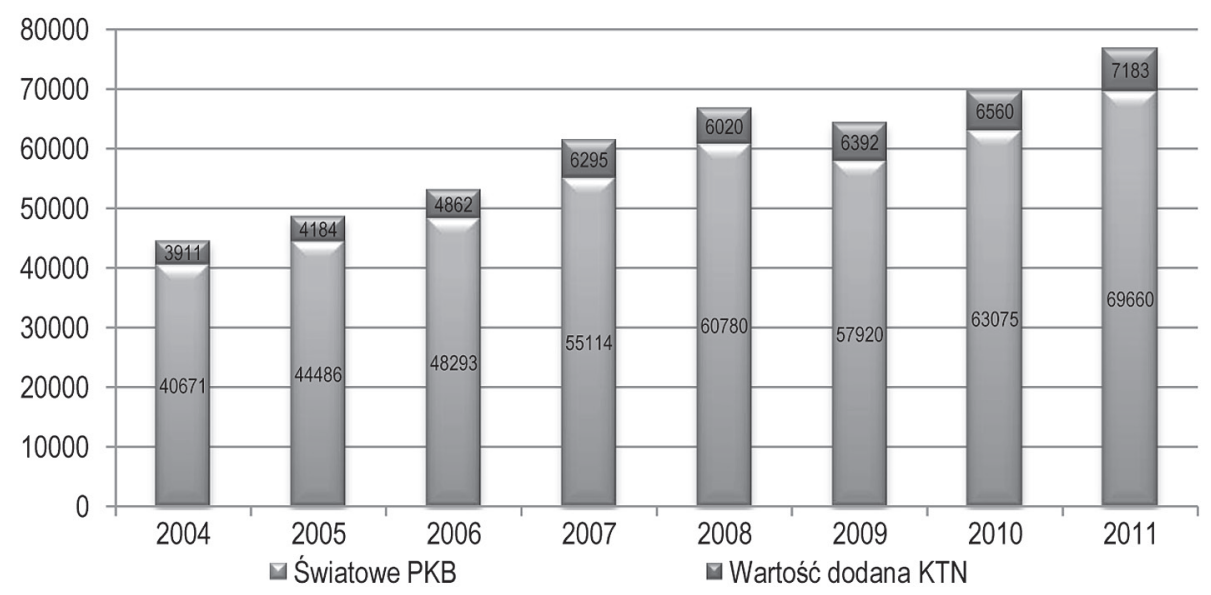

Wykres 2. Wartość dodana KTN i światowe BKB w latach 2004-2011 (w mld USD)

Źródło: World Investment Report 2012, UNCTAD, s. 24, World Investment Report 2009, UNCTAD, s. 18, World Investment Report 2007, UNCTAD, s. 9, World Investment Report 2005, UNCTAD, s. 14.

Godny uwagi jest fakt, iż kryzys z 2008 roku odcisnął się piętnem na wiele parametrach dotyczących poszczególnych gospodarek, jak i gospodarki światowej. Można to zaobserwować chociażby śledząc w kolejnych latach wielkość światowego PKB, lecz jeśli przyjrzymy się wartości dodanej KTN w tym okresie, to pomimo kryzysu i spadku zasobów BIZ wartość ta nieustannie rośnie.

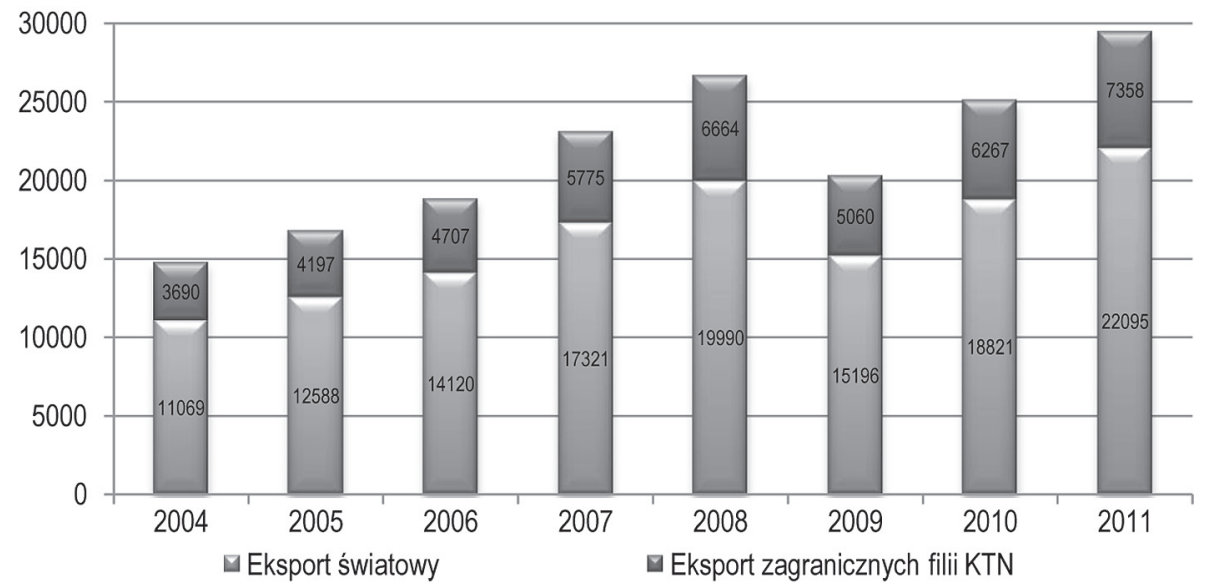

Wykres 3. Wartość eksportu zagranicznych filii KTN i światowy eksport w latach 2004-2011 (w mld USD) Źródło: World Investment Report 2012, UNCTAD, s. 24, World Investment Report 2009, UNCTAD, s. 18, World Investment Report 2007, UNCTAD, s. 9, World Investment Report 2005, UNCTAD, s. 14. 
Relacja eksportu zagranicznych filii KTN do eksportu światowego w latach 2004-2011 wynosiła przez cały ten okres 33\%. Również dalsze prognozy na lata kolejne dotyczące wartości światowego BIZ są optymistyczne.

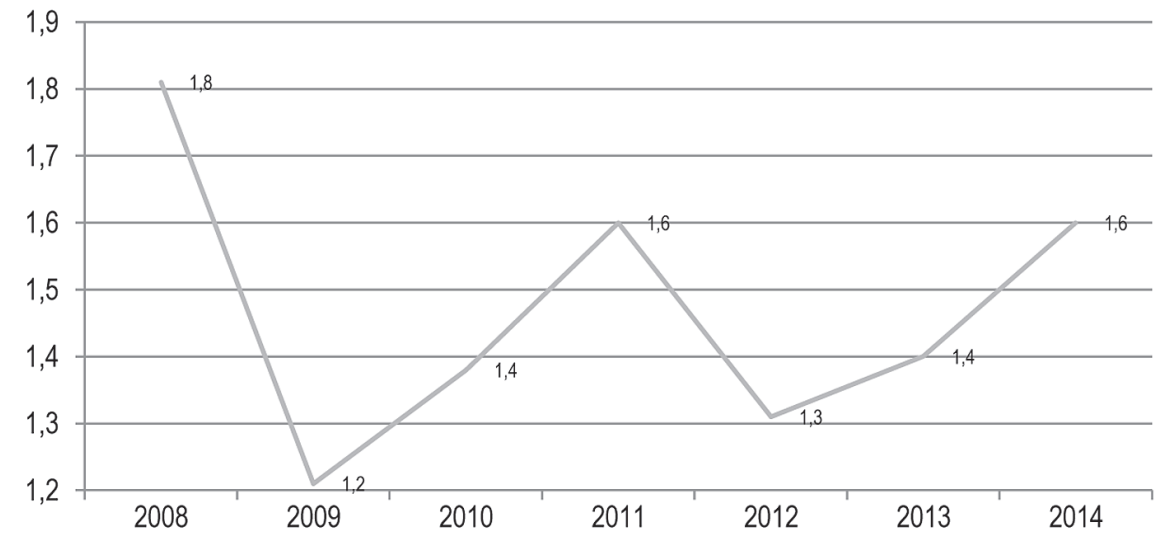

Wykres 4. Wartość światowego BIZ w latach 2008-2014 (prognoza) (w trylionach USD) Źródło: Global FDI recovery derails, "Global Investment Trends Monitor" 2013, nr.11, s. 2, 5.

W przepływach BIZ znaczenie korporacji transnarodowych jest bardzo duże. Ocenia się, że na 500 największych inwestorów przypada około 80\% przepływów BIZ na świecie ${ }^{20}$.

\section{ZAKOŃCZENIE}

Korporacje transnarodowe są szczególnym rodzajem podmiotów gospodarki światowej. Ich specyfika wynika m.in. z faktu dysponowania wielkim potencjałem ekonomicznym, względnej niezależności finansowej, technologicznej i organizacyjnej. Bezpośrednie Inwestycje Zagraniczne pozwoliły Korporacjom Transnarodowym stać się stymulatorami zmian we współczesnej gospodarce światowej. Przepływy kapitałowe są zjawiskiem nierozerwalnie związanym ze współczesną gospodarką, stanowią kluczowy element rozwoju korporacji.

\section{BIBLIOGRAFIA}

Bednarz J., Gostomski E., Pozyskiwanie kapitatu na dziatalność gospodarczq na rynkach zagranicznych, WUG, Gdańsk 2008.

20 A. Zaorska, Korporacje transnarodowe, przemiany, oddziatywania, wyzwania, PWE, Warszawa 2007 , s. 110. 
Ciecierski M., Wywiad Biznesowy w korporacjach transnarodowych, Wydawnictwo Adam Marszałek, Torun 2009.

Drelich-Skulska B., Skulski P., Specyfika biznesu międzynarodowego w Azji Wschodniej na tle procesów globalizacji, [w:] E. Najlepszy, M. Bartosik-Purgat (red.), Determinanty $i$ wyzwania gospodarki światowej, UE, Poznań 2009.

Dzikowska M., Wptyw kryzysu finansowego i ekonomicznego na dziatalnośc korporacji transnarodowych w latach 2008-2010, [w:] J. Schroeder (red.), Przedsiębiorstwo na rynku międzynarodowym, WUE, Poznań 2011.

Fojutowski Ł., Strategie przedsiębiorstw krajowych wobec ekspansji korporacji transnarodowych. Uwarunkowania regionalne, WSNHiD, Poznań 2011.

Franc-Dąbrowska J., Porada-Rochon M., Bezpośrednie inwestycje zagraniczne - perspektywa międzynarodowa, „Przegląd Organizacji” 4/2010.

Frejtag-Mika E., Architektura finansowa globalnej wspótpracy na rzecz rozwoju- wyzwania milenijne, [w:] J. L. Bednarczyk, S. I. Bukowski, J. Misala (red.), Globalne rynki finansowe w dobie kryzysu, CeDeWu, Warszawa 2009.

Garniewicz G., Siemiątkowski P., Wprowadzenie do międzynarodowych przeptywów kapitatu, Wydawnictwo „Dom Organizatora”, Torun 2006.

Global FDI recovery derails, „Global Investment Trends Monitor” 2013, nr.11.

Kola-Bezka M., Kuzel M., Sobczak I., BIZ w województwie kujawsko-pomorskim, WSG, Bydgoszcz 2009.

Kolarz M., Wptyw zagranicznych inwestycji bezpośrednich na innowacyjnośc przedsiębiorstw w Polsce, WUS, Katowice 2006.

Kuciński K., Glokalizacja, Difin, Warszawa 2011.

Kuzel M., Rola Bezpośrednich Inwestycji Zagranicznych w dyfuzji wiedzy i umiejętności, Dom Organizatora, Torun 2007.

Lech M., Zdolność oddziatywania korporacji transnarodowych na wspótczesne stosunki międzynarodowe w dobie procesu globalizacji, [w:] J. Menkes, T. Gardocka (red.), Korporacje transnarodowe, Academika, Warszawa 2010.

Lundan S. M., An institutional perspective on the social responsibility of TNCs, „Transnational Corporation", 2011.

Macias J., Nowa strategia transnarodowa korporacji międzynarodowych - globalna standaryzacja i lokalna wrà̇liwość, „Przegląd Organizacji”, nr 9/2010.

Marzec P., Korporacje transnarodowe w procesie globalizacji gospodarki swiatowej, [w:] T. Guz, K. A. Kłosiński, P. Marzec (red.), Polska, Europa, Świat. Korporacje transnarodowe, Polihymnia, Lublin-Tomaszów Lubelski 2007.

Marzęda K., Proces globalizacji korporacyjnej, Branta, Bydgoszcz - Warszawa - Lublin 2007.

OECD, Benchmark Definition of Foreign Direct Investment, Paris 1996.

Pakulska T., Poniatowska-Jaksch M., Korporacje transnarodowe a globalne pozyskiwanie zasobów, SGH, Warszawa 2009.

Piech K., Integracja rynków finansowych w Unii Europejskiej, NBP, Warszawa 2007.

Sokołowicz M.E., Region w gospodarce globalnej - bezpośrednie inwestycje zagraniczne a rozwoój regionu, [w:] A. Nowakowska, Z. Przygodzki, M.E. Sokołowicz (red.), Region w gospodarce opartej na wiedzy, Difin, Warszawa 2011. 
Sowa K., Strategie konkurencji korporacji ponadnarodowych, Difin, Warszawa 2006.

Sporek T., Wptyw kryzysu finansowego na globalizacje gospodarki swiatowej. Diagnoza $i$ konsekwencje dla Polski, WAE, Katowice 2010.

Stępień B., Przedsiębiorstwo międzynarodowe - trudności analityczne, [w:] J. Schroeder (red.), Perspektywy i kierunki rozwoju przedsiębiorstw międzynarodowych, Poznań 2006.

Szelągowska A., Inwestycje międzynarodowe przedsiębiorstw, [w:] A. Kosztowniak, P. Misztal, I. Pszczółka, A. Szelągowska (red.), Finanse i rozliczenia międzynarodowe, C.H. Beck, Warszawa 2009.

UNCTAD, World Investment Report 2005.

UNCTAD, World Investment Report 2007.

UNCTAD, World Investment Report 2009.

UNCTAD, World Investment Report 2012.

Urbanek J., Ewolucja modeli organizacyjnych w korporacjach transnarodowych, a korporacje transnarodowe przysztości, [w:] J. Rymarczyk (red.), Rozwój regionalny i globalny we wspótczesnej gospodarce światowej, WAE, Wrocław 2005.

Waśniewski K., Decyzje inwestycyjne wspótczesnej korporacji - dylematy racjonalności, KTE, Kraków 2011.

Zaorska A., Korporacje transnarodowe, przemiany, oddziatywania, wyzwania, PWE, Warszawa 2007. 
